\begin{tabular}{|c|c|c|c|}
\hline & $\begin{array}{l}\text { Escola Superior } \\
\text { de Gestäoo e } \\
\text { Tecnologia } \\
\text { [ipSantarém] }\end{array}$ & 陑而 & $\begin{array}{l}\text { ISSN 2029-7564 (online) } \\
\text { SOCIALINEES TECHNOLOGIJOS } \\
\text { SOCIAL TECHNOLOGIES } \\
2014,4(2) \text {, p. } 370-384\end{array}$ \\
\hline
\end{tabular}

\title{
BENDRUOMENINIŲ IR NEVYRIAUSYBINIŲ NE PELNO SIEKIANČIŲ ORGANIZACIJŲ VEIKLOS TRADICIJOS IR VADYBOS PERSPEKTYVOS LIETUVOJE
}

\author{
Andrius Stasiukynas \\ Mykolo Romerio universitetas, Lietuva, stasiukynas@mruni.eu \\ doi:10.13165/ST-14-4-2-10
}

\section{Santrauka}

Tikslas - apžvelgti bendruomeninių ir nevyriausybinių ne pelno siekiančiu organizaciju veiklos tradicijas ir vadybos perspektyvas Lietuvoje.

Metodologija. Siekiant tyrimo tikslo yra atlikta literatūros analizė bei nagrinèti keli sèkmingos veiklos patirti turinčiu organizacijų atvejai Lietuvoje. Išsamesnei atveju informacijai surinkti buvo nagrinetos organizaciju veiklos ataskaitos, nuostatai (istatai), valdymo organu susirinkimu protokolai bei atkliktas empirinis tyrimas, apklausiant organizaciju valdymo organu atstovus.

Rezultatai - tyrimas atskleide bendruomeniniu ir nevyriausybiniu organizaciju skaičiaus didëjimo tendencijas ir trukdžius juvertinti realiai veikiančiu šių organizacijų apimtis. Atskleisti „trečiajam“ sektoriui aktualūs vadybos aspektai ir ju pagrindu išnagrinètos gerosios patirtys leido daryti prielaidas del nevyriausybiniu ir bendruomeniniu organizaciju vadybos perspektyvu, iš kuriu pažymėtinos: 1) augs poreikis tobulinti kompetencijas, susijusias su komunikacija ir bendradarbiavimu; 2) žmogiškuju ištekliu vadyboje turès daugèti inovatyviu vadybos metodu, atitinkančiu besikeičiančios organizacijos aplinkos ir nariu kompetenciju kaitos tendencijas; 3) stiprès skaitmeninio turinio technologiniu irankiu poreikis organizaciju vadyboje.

Tyrimo ribotumas - trečiojo sektoriaus organizacijų veikloje labai svarbus žmogiškuju ištekliu vadybos aspektas, kuris nebuvo nuodugniau tyrinètas. Bütų vertinga toliau tirti žmogiškujų ištekliu vadybą, ypač bendruomeninių organizacijų kontekste. 
Praktiné reikšmé - tyrimas atskleidè nevyriausybinių ir bendruomeninių organizaciju vadybos aspektus, kurie turi įtakos šiu organizaciju stiprinimui.

Vertingumas - tyrimas papilde žinias apie bendruomeninių ir nevyriausybiniu organizaciju raida bei vadybos tendencijas.

Raktažodžiai - bendruomene, ne pelno nevyriausybiné organizacija, bendruomeniniu ir nevyriausybiniu organizaciju vadyba.

Tyrimo tipas - literatūros apžvalga, tyrimo pristatymas.

\section{Itvadas}

Bendruomenių ir nevyriausybinių ne pelno siekiančių organizacijų (NVO) veiklos aktyvumas Vakarų šalyse sietinas su pilietiškumo ir demokratijos sklaida bei gebejjimu spręsti socialinius ir kitus iššūkius lokalioje aplinkoje, pasiremiant vietos gyventojų iniciatyvomis ir, tik esant poreikiui, pritraukiant viešosios valdžios atstovus. Lietuvoje nuo nepriklausomybès atkūrimo kasmet kuriasi naujos NVO, buriasi bendruomenès, tačiau viešosios valdžios atstovai teigia, kad situacija, susijusi su demokratija ar tokių organizacijų ịtraukimu ì socialinių ar kitų problemų sprendimą, mažai tepasikeitè. Viena iš priežasčių, kodèl viešųjų paslaugų perdavimas NVO nèra ígyvendinamas Lietuvoje, yra nepasitikejjimas šio (trečiojo) sektoriaus vadybinèmis kompetencijomis.

Bendruomeninès ir nevyriausybinès organizacijos pasižymi bruožais, išskiriančiais jas iš privataus ir valstybinio sektorių. Šiam, „trečiajam“ sektoriui būdinga pilietiška veikla (tiek politinè-pilietinè, tiek labdaringa-pilietinė), paremta savanoryste ir socialinių ryšių stiprinimu. Ne pelno siekiančio nevyriausybinio sektoriaus ypatumai nulemia ir vadybos metodų specifiškumą bei galimybes taikyti gerąsias kituose sektoriuose vyraujančias vadybos patirtis.

Išties, Lietuvos bendruomeninių ir nevyriausybinių organizacijų vadybiniai gebèjimai yra mažai tyrinèti, paminètini Aleksandravičius ir Žukovskis (2011), Ališauskas, Jankauskienè ir Kairytė (2008), Bagdonienė, Daunorienė, Simanavičienė (2011), Čepienė (2011), Grigas (2010), Guogis, Gudelis ir Stasiukynas (2006), Jakutyte (2012), Juozaitis ir Vilimienè (2000), Nefas $(2007,2011)$, Žuromskaite (2014) ir kiti autoriai, kurie bandè užčiuopti vieną ar kitą Lietuvos NVO vadybos ar bendruomenès funkcionalumo aspektą, tačiau išsamesnių Lietuvos trečiojo sektoriaus raidos apžvalgų vadybos aspektu stokojama.

Šiuo straipsniu siekiama tirti bendruomeninių ir nevyriausybinių organizacijų veiklas vadybos aspektu, todèl formuluotinas tyrimo tikslas - apžvelgti bendruomeninių ir nevyriausybinių ne pelno siekiančių organizacijų veiklos tradicijas ir vadybos perspektyvas Lietuvoje.

Tikslui pasiekti formuluotini uždaviniai:

1. Išnagrinèti bendruomeninių ir nevyriausybinių ne pelno organizacijų veiklos tikslus ir apžvelgti pagrindinius vadybos aspektus.

2. Apžvelgti bendruomeninių ir nevyriausybinių ne pelno organizacijų raidą Lietuvoje. 
3. Ištirti pasirinktų bendruomeninių ir nevyriausybinių ne pelno organizacijų veiklos tendencijas ir perspektyvas išskirtais vadybos aspektais.

\section{Tyrimo metodika}

Siekiant tyrimo tikslo yra atlikta literatūros analizè bei nagrinèti keli sèkmingos veiklos patirtị turinčių organizacijų atvejai Lietuvoje. Išsamesnei atvejų informacijai surinkti buvo nagrinètos organizacijų veiklos ataskaitos, nuostatai (įstatai), valdymo organų susirinkimų protokolai bei atliktas empirinis tyrimas, apklausiant organizacijų valdymo organų atstovus. Organizacijos atrinktos pagal pozityvų žinomumą visuomenèje (jų vadovai traktuojami kaip ekspertai, pvz., dalyvauja televizijos ir radijo laidose, yra kviesti dalyvauti oficialiose darbo grupèse prie viešosios valdžios institucijų, taip pat jų vadovaujamos organizacijos yra užsirekomendavusios kaip patikimos stambių projektų igyvendintojos). Tyrimui pasirinktos: Vilniaus Balsių bendruomenė (ikurta 2002 m.) (BNO1) bei Lietuvos blaivybės fondas (¡kurta 1992 m.) (BNO2) ir jaunimo organizacija LKJBS „Žingsnis“ (¡kurta 1997 m.) (BNO3).

\section{Bendruomeninès ir nevyriausybinès ne pelno siekiančios organizacijos bei jų vadybos prielaidos}

Šiame skyriuje nagrinëjamos bendruomeninių ir nevyriausybinių ne pelno organizacijų veiklos prielaidos, tikslai ir apžvelgiami pagrindiniai vadybos aspektai, kurie sudarys sąlygas atlikti empirinį tyrimą.

Bendruomenès apibrèžimo platumas suponuoja ịvairius požiūrius ị bendruomenès gyvenimą, raidą ar vystymą. Bendruomenė suprantama kaip žmonės, tarpusavyje susiję ne tik kaip kaimynai, turintys kažką bendro, bet ir kaip žmonès, kuriuos sieja bendra patirtis (Block, 2008). Kitaip tariant, bendruomenès nariai - tai žmonės, savo laisvu pasirinkimu susivieniję bendram tikslui. Bendruomenè šiuo metu yra vieta, kur žmogus susiformuoja kaip asmenybė, o kiekvieną asmenybę, nors ji ir unikali, su kitais jungia nematomas bendrystės jausmas (Blackshaw, 2010). Etzioni (2011) taip pat pabréžia emocinio ryšio svarbą. Jis pažymi, kad:

- bendruomenès nariai yra sujungti vienas su kitu emociniais ryšiais;

- bendruomenès narius vienija ne tik bendri interesai, bet ir vienodos vertybès;

- bendruomenès nariai yra linkę aukotis dèl vienas kito ir bendruomenès gerovès.

Autoriaus pateikiami bendruomenès požymiai atitinka kelis iš esminių McMillano ir Chaviso (1986) teorijos elementų, formuojančių bendruomeniškumą.

Lietuvos viešosios valdžios požiūrị atskleidžia Vietos savivaldos îstatyme (Žin., 1994, Nr. 55-1049) pateikiama savivaldybès bendruomenès samprata - savivaldybès bendruomenè suprantama kaip savivaldybès nuolatiniai gyventojai, bendrais viešaisiais poreikiais, interesais ir savivaldos teisiniais santykiais susieti su savivaldybès taryba ir kitais viešojo administravimo funkcijas atliekančiais savivaldybės subjektais. Ši samprata apima žmones, viešąsias institucijas ir atsirandančius santykius siekiant patenkinti poreikius ir spręsti problemas. 
Vadybos mokslo požiūriu nagrinèjama bendruomenè igyja organizacijos požymius, kurie leidžia vertinti bendruomenės veiklą, analizuoti rezultatus, darančius ịtaką kitų socialinių reiškinių gyvavimui.

S. Nefas (2007) siūlo ị bendruomenę žiūrèti per funkcionalumo dimensiją, kai bendrus teritorijos ir interesų kriterijus papildo bendro veiksmo kriterijus, susijęs su socialinių funkcijų atlikimu. Nefo nuomone, funkcionali vietos bendruomenė yra grupé žmonių, kurie gyvena apibrèžtoje teritorijoje ir atlieka tam tikrus veiksmus tos vietos labui, dèl ko atsiranda bendri interesai ir vidinis jausmas, jog jie priklauso tai pačiai žmonių grupei (Nefas, 2007). Pažymètina, kad mokslininkas atkreipia dèmesĭ, jog funkcionalios bendruomenès apibrèžimas Vakarų mokslininkų tapatinamas su pilietinès bendruomenès samprata (Nefas, 2011).

Vadybos požiūriu nagrinèti bendruomenę labiau tiktų bendruomeninès organizacijos terminas, kuris apibrèžiamas Vietos savivaldos įstatyme (Žin., 1994, Nr. 55-1049): „bendruomeninè organizacija - asociacija, kurios steigejjai ir nariai yra gyvenamosios vietovés bendruomenès (jos dalies arba kelių gyvenamųjų vietovių) gyventojai (jų atstovai) ir kurios paskirtis - per iniciatyvas igyvendinti viešuosius interesus, susijusius su gyvenimu kaimynystėje“. Pažymètina, kad termino apibrèžimas sudaro sąlygas nagrinèti bendruomenès narių veiklą per organizacijų vadybos prizmę ir ją lengviau analizuoti nevyriausybinių organizacijų vadybos kontekste.

Dèl didelès nevyriausybinių ne pelno siekiančių organizacijų ịvairovès sunku suformuluoti bendras ir visoms NVO tinkančias funkcijas. Lewis (2000) nurodo ịvairius nevyriausybinių ne pelno siekiančių organizacijų vaidmenis: (i) vykdytojai, teikiantys viešąsias paslaugas, kurios dažnai būna inicijuotos ir remiamos valstybinio sektoriaus organizacijų; (ii) katalizatoriai, inicijuojantys veiklas ir projektus tiek vietos lygmeniu, tiek siekiant daryti įtaką viešajai politikai; (iii) partneriai, kurie plètoja ryšius bei partnerystę, neprarandant savarankiškumo. Ilgius (1999) teigia, kad pagrindines NVO funkcijos: paslaugų teikimas; interesų atstovavimas; savitarpio pagalba arba pagalba sau; ištekliai ir koordinavimas. Fungas (2003) išskiria interesų gynimą ir atstovavimą; piliečių socializaciją; pasipriešinimą ir galios kontrolę. Mačiukaitė-Žvinienè ir Grigaliūnaitė (2006) taip pat pabrěžia skirtingų visuomenès grupių interesų atstovavimą. Banksas ir Hulme'as (2012) NVO ịvardina kaip paslaugas visuomenei teikiančias ir jos poreikiais besirūpinančias organizacijas, kurios geba daryti įtaką visuomenei. Jakutytė (2012) apibendrindama įvairius autorius teigia, kad ne pelno organizacijos atlieka patariamąją, piliečių įtraukimo ị bendrų tikslu igyvendinimą bei tarpininkavimo tarp valdžios ir piliečių funkcijas. Apskritai literatūroje, nagrinejjančioje nevyriausybinio sektoriaus veiklos problematiką, dažnai akcentuojamos NVO veiklos, susijusios su interesų, ypač socialiai pažeidžiamų grupių, atstovavimu bei pagalba ar paslaugų teikimu toms grupėms, kurioms neteikia nei valstybinis, nei privatus sektoriai.

Taigi, stiprios ir savarankiškos NVO gali tarnauti tiek visos visuomenès interesams atstovavimo, demokratijos puoselejjimo srityse; tiek užpildyti „baltąsias dėmes“ socialinių paslaugų teikimo, pagalbos rizikos grupèms, kvalifikacijos kèlimo bei kitose visuomenei svarbiose srityse. Pažymètina, kad dèl savo veiklos specifikos jos dažnai yra populiaresnès tarp klientų ir neretai jiems kelia daugiau pasitikejjimo. Jos gali sẻkmingiau pasiekti vadinamąsias problemines visuomenes grupes bei suteikti joms efektyvią pagalbą (Stasiukynas ir Žuromskaité, 2014). 
Atsižvelgiant $\mathfrak{i}$ paminètas NVO bendrąsias funkcijas ir tikslus galima teigti, kad NVO gali vaidinti skirtingus vaidmenis, iš kurių išskirtume: 1) NVO, kuriančios socialinị efektą (paslaugas teikiančios organizacijos, dar vadinamos pasiūlos nevyriausybinėmis organizacijomis); 2) veikiančios interesų gynimo srityje, advokataujančios (siekiančios daryti ịtaką viešajai politikai, skleidžiančios propagandą, vadinamos paklausos nevyriausybinėmis organizacijomis). Pažymėtina, kad dažnai ta pati NVO vaidina skirtingus vaidmenis, priklausomai nuo tikslinės grupès, kurios naudai ši organizacija yra sukurta.

NVO vadybos prielaidos. Organizacijos vidaus aplinka sietina su organizacijoje taikomais vadybiniais modeliais, organizacijos darbuotojais savanoriais, organizacijos žmogiškuoju kapitalu ir t. t., t. y. priemonèmis, kurios padeda organizacijai pasiekti užsibrèžtus tikslus. Jei individai, dalyvaujantys šios organizacijos „paslaugų gamyboje“ bus kompetentingi, tai ir bus sudaromos palankios sąlygos kokybiškam (sėkmingam) „paslaugų teikimui“ išorès aplinkoje (už organizacijos ribų). Atitinkamai, pagal JNVO veiklas galima išskirti jos personalo kompetencijas, reikalingas organizacijos sèkmingai veiklai.

Nevyriausybinès organizacijos veiklos efektyvumas gali būti vertinamas įvairiais aspektais, tačiau Lecy (2012) su bendraautoriais, išnagrinejję daugiau negu 60 skirtingų mokslinių šaltinių, išskiria tokius bendriausius efektyvumą nusakančius bruožus: (i) vadybinis efektyvumas - lyderystė, žmogiškųjų išteklių vystymas, finansų valdymas, planavimas ir t. t.; (ii) vykdomų programų efektyvumas - turètų būti vertinamas ne tik efektyvumas vykdomos programos lygmeniu, tačiau apibrežiamas organizacijos poveikis apskritai; (iii) tinklų efektyvumas - gali būti apibrèžtas kaip organizacijos gebèjimas mobilizuoti dalyvius arba pasiekti savo strateginius tikslus dalyvaujant tinkle; (iv) legitimumas ir reputacija - organizacijos vardas ar su juo susiję projektai gali tapti organizacijos prekès ženklu, pritraukti lešas ir igyti galią veikti politinius procesus, todèl nepriekaištingos reputacijos išlaikymas tampa jos veiklos legitimumo įrodymu.

Dažnai vienas iš NVO vertinimo kriterijų yra organizacijos turima patirtis. Geros praktikos pavyzdžių analizè leidžia analizuoti teigiamus ir neigiamus organizacijos veiklai įtakos turinčius veiksnius bei tinkamai suformuoti organizacijos veiklos strategiją. Sẻkmingai veikiančios NVO gali kitoms puikiai pademonstruoti rezultatyvios lešų paieškos, geros projektų vadybos, veiklos skaidrumo, atskaitomybès, narių ịtraukimo, savanoriškos veiklos, visuomenès informavimo kampanijų, koalicijos kūrimų ar lobizmo standartus (Bagdonienè ir kt., 2011). Taip pat tokios organizacijos turi kitų interesų grupių pripažinimą, pvz., veikdama vaikų neformalaus ugdymo srityje gali būti partnere tiek su viešojo valdymo institucijomis, tiek su nepriklausomais privačiais paslaugų teikejjais.

Telkiant NVO ir bendruomenes bei organizuojant jų veiklą svarbų vaidmenį atlieka lyderis (Schmitz, 2011), kuris suburia branduoli ir veda organizacijos narius suplanuotos vizijos link. Pažymėtina lyderio reikšmé visose "trečiojo“ sektoriaus veiklose, kurios vienaip ar kitaip susijusios su žmonių veikla (Grigas, 2010; Nefas, 2007; Schmitz, 2012).

Druckeris (1995) pabrèžia, kad organizacijos misija yra NVO veiklos pagrindas, ji atspindi organizacijos vertybes, ịsitikinimus bei visuomenès poreikius. Ne mažiau svarbi strategija, kadangi praradus strategiją organizacija nustos vystytis, o ilgainiui ir veikti.

Sèkmingai NVO veiklai svarbus ir jau minètas teigiamas organizacijos įvaizdis (reputacija), kuris indikuoja apie sèkmingą organizacijos veiklą.

Didžiausias NVO turtas - žmogiškieji ištekliai. Neretai NVO organizacijos tampa pirmuoju karjeros laipteliu bei galimybe užmegzti naujus kontaktus (ypač jauniems spe- 
cialistams). Taip pat nevyriausybinėse organizacijose labai svarbus yra darbuotojų vaidmuo organizacijos vadyboje, nes darbuotojai ateina ị šio tipo organizacijas ne tik dirbti, bet ir prisidèti prie misijos igyvendinimo bei aktyviai dalyvauti sprendžiant problemas (Stasiukynas ir Žuromskaitè, 2014).

Išskirtinė NVO padėtis žmogiškųjų išteklių prasme, nes personalo veikla paremta savanorišku darbu. Ypatingą reikšmę igyja darbas su savanoriais, jų motyvavimas bei komandinis darbas. Problemos sprendžiamos komandoje, ittraukiant kuo daugiau organizacijos bendruomenès narių, stiprina ir pačią organizaciją kokybiškai (Čepienè, 2011). A. M. Juozaitis ir R. Vilimienè (2000) mano, kad geriausia komandos formavimo priemonè yra bendras nevyriausybinès organizacijos dalyvių strategijos kūrimas. Čepienė (2011) teigia, kad sprendimų prièmimas komandoje ją vienija ir ruošia bendroms veikloms sprendžiant šias problemas. Komandiniu darbu paremtai organizacijai lengviau pasiekti užsibrèžtus tikslus bei pritraukti bendraminčius.

Nagrinėdamas Lietuvos bendruomenių veiklos veiksnius ir motyvus Ališauskas su bendraautoriais (2008) pažymėjo svarbų bendruomenès veiklos palaikymo ir aktyvinimo faktorių, kurị gali atlikti tiek bendruomenès lyderiai ir aktyvesni dalyviai iš vidaus, tiek plačioji visuomenė ir valdžios institucijos iš išorès (moralinis bei finansinis palaikymai vaidina svarbų vaidmenị). Aleksandravičius ir Žukovskis (2011) pažymi bendruomenès gebejjimą būti atvira ir sugebejjimą prisitaikyti prie ịvairių naujų sąlygų, kaip veiksnį, turintị didelę ịtaką veiklos sèkmei.

Remiantis Lietuvos organizacijų vadybos atvejų analize (Stasiukynas ir Žuromskaitè, 2014), išskirtini veiksniai, turintys įtakos sèkmingai JNVO veiklai: (i) lyderių komunikacijos, kūrybingumo, komandinio darbo ir kiti gebėjimai; (ii) organizacinè kultūra, skatinanti komandinị darbą, kūrybingumą, saviraišką ir demokratinius procesus; (iii) darbuotojų savanorių pritraukimo, darbų skirstymo ir motyvavimo mechanizmai; (iv) dirbančių kompetencijos (darbo organizavimas; projektų bei finansų valdymas ir kita).

Apibendrinant galima išskirti bendruomeninių ir nevyriausybinių organizacijų veiklos sritis, svarbias organizacijos vadybai:

- lyderiai, vadovavimas organizacijai,

- Žmogiškųjų išteklių sutelkimas ir aktyvinimas įtraukiant ị veiklą,

- organizacijos narių bendradarbiavimas, komandinis darbas,

- organizacijos narių kompetencijos.

Išskirti vadybos aspektai sudaro prielaidas tolesniam empiriniam bendruomeniniu ir nevyriausybinių organizacijų tyrimui.

\section{Bendruomeninių ir nevyriausybinių organizacijų raida Lietuvoje}

Bendruomeninių organizacijų plètros proveržis, kaip ir apskritai nevyriausybinio ne pelno sektoriaus, Lietuvoje sietini su nepriklausomybės paskelbimu. Lietuvoje NVO skaičius augo iki Antrojo pasaulinio karo, bet po nepriklausomybès praradimo situacija pasikeitè, pilietinès iniciatyvos buvo ribojamos valdžios (liko visuomeninès organizacijos ir kooperatyvai (Šimašius, 2007).

Sovietinis laikotarpis neigiamai paveikè nevyriausybinių organizacijų veiklą ne tik Lietuvoje, bet ir kitose posovietinèse respublikose (Marček, 2008). Tik po komunizmo 
žlugimo šiose šalyse atsiverè naujos galimybės pilietinės visuomenės bei NVO vystymuisi. Kaip rodo naujausi mokslininkų tyrimai buvusiose Sovietų Sąjungos respublikose, atgaivinti pilietinę visuomenę buvo įmanoma tik atkuriant nacionalinę tapatybę bei piliečių tarpusavio pasitikẻjimą (Kèrytè, 2010).

Po Lietuvos valstybės nepriklausomybės atkūrimo šalyje tvyrojo patriotiškumo, tautiškumo, visuomeniškų iniciatyvų nuotaikos. Stiprų atgarsį sulaukè blaivybès (nesisvaiginančios, blaiviai mąstančios, nepaveiktos „primesta ideologija " tautos) idejjos. Atsikūre gyvavusios iki Antrojo pasaulinio karo NVO (pvz., Ateitininkų federacija, Lietuvos skautija ir kitos) ar formalizavosi pogrindyje veikusios neformalios pilietinès iniciatyvos, steigèsi naujos organizacijos (pvz., „Socialinès tarnystės savanoriai“, LKJBS „Žingsnis“ ir kitos). Populiarumą prarado ryškų ideologini pagrindą turejjusios „spaliukų“, „pionierių“ ir panašios organizacijos, tad „veiklus“ jaunimas ypatingai aktyviai ieškojo naujų veiklos nišųu, sričių, kurios atitiktų visuomenèje vyraujančias nuotaikas.

Pažymètina, kad ženklų indèlị ị NVO ir bendruomenių plètrą įnešė Vakarų valstybių (paminètinos Švedija, JAV) finansinè ir kitokia parama. I Lietuvą plūstelèjo naujų (neiprastų) veiklų idejjos ir metodai. Visuomeninių veiklų prasmingumas ir kryptingas užimtumas igyvendinamas kitokiais, nei buvo ịprasta iki tol, metodais buvo labai patrauklus jauniems, iniciatyviems žmonèms.

Apžvelgiant per 1992-1997 metus įsteigtų ịvairių visuomeninių organizacijų nuostatus, galima teigti, kad tautiškumas, patriotiškumas, pagalba artimui, blaivybe ir panašios vertybės buvo vyraujančios (Stasiukynas ir Žuromskaite, 2014).

Nevyriausybinis sektorius laikytinas vienu iš greičiausiai besivystančių Europoje (Domański, 2010). Lietuvoje taip pat šis sektorius plètèsi kiekybiškai (1995 m. buvo užregistruota 260 visuomeninès organizacijos, tuo tarpu $2005 \mathrm{~m}$. jau apie 15 tūkst.). İvairūs finansiniai mechanizmai skatino burtis ir stiprino NVO sektorių: Pasirengimo narystei Europos Sąungoje (PHARE programa), vèliau Europos Sąjungos bei Europos ekonominès erdvės narėms stiprinti mechanizmai. Didelę ịtaką kaimo bendruomenių plètrai turejjo kaimo bendruomenių remimo schemos. Tačiau ir dabar NVO organizacijų skaičius ir veikla priklauso nuo šalies ekonominès ir politinės situacijos (Matonyté, 2003). Būtina pabrèžti, kad Lietuvoje lètesnei nevyriausybinių organizacijų raidai įtakos turëjo lietuvių politinis pasyvumas (Kèrytė, 2010) bei neturëjimas pakankamai autoritetų ir įtakos (Guogis ir kt., 2007).

Pažymètina, kad Lietuvoje nèra vienos NVO statistinès duomenų bazès ir didelè dalis registruotų organizacijų nevykdo jokios veiklos. Pagrindinè priežastis ta, kad NVO remiasi savanorišku darbu ir Lietuvoje sistemingo šios srities organizacijų finansavimo nẻra, o organizacijos veiklos oficialus nutraukimas bei išregistravimas reikalauja papildomų ištekių.

\section{Bendruomeninių ir nevyriausybinių ne pelno organizacijų vadybos raida ir tendencijos išskirtais vadybos aspektais}

Toliau pateikiama empiriniame tyrime dalyvavusių organizacijų veikla per dvidešimties metų laikotarpi pirmoje dalyje išskirtais vadybos aspektais (organizacijų lyderiai, vadovavimas organizacijai; žmogiškųjų išteklių sutelkimas ir aktyvinimas įtraukiant ị 
veiklą; organizacijos narių bendradarbiavimas, komandinis darbas; organizacijos narių kompetencijos).

Empirinio tyrimo imtis. Empiriniam tyrimui pasirinktos organizacijos, turinčios veiklos plètros gerosios patirties pavyzdžių ir sulaukusios ženklaus palaikymo iš visuomenès bei valstybinio valdymo institucijų.

BNO1 - bendruomeninė organizacija (ịsteigta 2002 m.), pasižyminti savo plètra tiek bendruomenès kiekybiniu (per pastarąji dešimtmetị skaičius padvigubėjo ir $2014 \mathrm{~m}$. turẻjo daugiau negu 10 tūkst. narių), tiek vykdomų infrastruktūros ir kitų projektų (viešosios ir privačios partnerystès pagrindu pastatyta ir sèkmingai veikia bendrojo lavinimo mokykla; kuriamas mitologinis parkas; aktyviai organizuoja kultūros, sporto ir aktyvaus laisvalaikio bei kitus renginius; vykdo „saugios kaimynystès“, pilietiškumo ir socialinio verslumo skatinimo bei kitus projektus).

BNO2 yra 1992 m. įsteigta (1997 m. perregistruota) asociacija, jungianti didžiausias Lietuvos visuomenines organizacijas, puoselẻjančias blaivybės idejjas ir orientuojančias savo veiklą ì pilietiškos asmenybès, gebančios savarankiškai pasirinkti ir laisvos nuo priklausomybių, ugdymą. BNO2 narès yra Vyskupo M. Valančiaus blaivystès sąjūdis (per 4700 narių), Lietuvos krikščioniškojo jaunimo blaivybès sąjunga „Žingsnis“ (per 1000 narių), „Baltų ainiai“ (per 400 narių), draugija „Šalpa“. BNO1 aktyviai bendradarbiauja tiek su tarptautinėmis užsienio (Švedijos „Hela manniskan“ organizacija, Airijos „Community Awareness of Drugs“, Šiaurès šalių alkoholio ir narkotikų prevencijos organizacija NordAN, pasauline „Kettill Brunn“ alkoholio tyrimų asociacija, JAV Čikagos Medicinos centru), tiek su Lietuvos organizacijomis bei valstybinėmis institucijomis (LR Seimo sveikatos reikalų komitetu, Seimo narkomanijos prevencijos komisija, LR švietimo ir mokslo ministerija, Vilniaus m. vaikų teisių apsaugos tarnyba, Vilniaus m. švietimo skyriumi, Vilniaus edukologijos universitetu, Šiaulių universitetu, Klaipèdos universitetu, Pedagogų profesinès raidos centru, Valstybiniu psichikos sveikatos centru, Lietuvos katalikų mokslo akademija ir t. t.). BNO1 yra vykdęs per 40 projektų ir 13 ịvairių programų. 2009-2010 m. BNO1 vykdè Europos ekonominès erdvès ir Norvegijos finansinių mechanizmų subsidijų schemos „Nevyriausybinių organizacijų sektoriaus stiprinimas Lietuvoje“ projektą „Blaivi karta“.

BNO3 - yra $1997 \mathrm{~m}$. ikurta, jaunimą vienijanti ir socialinės vadybos metodais su jaunimu dirbanti organizacija, savo veikla siekianti ugdyti jaunimo saviraišką, kūrybiškumą, sveiką gyvenimo būdą. Per pastarąji dešimtmetị organizacija išaugo nuo kelių šimtų iki tūkstančio ir daugiau narių, Lietuvos skirtingose savivaldybèse veikia per 20 skyrių. Bendradarbiaujat su „International Snowball Association“ konsultuoja ir savanoriška veikla remia organizacijas, vykdančias panašias programas Europoje (Lenkijoje, Latvijoje, Baltarusijoje ir kt.). Organizacija visuomenei ir specialistams žinoma dèl sèkmingai vykdomų žalingų ípročių prevencijos programų (pažymètina "Sniego gniūžtès“ („Operation Snowball“) programa). BNO3 už savo visuomenei naudingą veiklą yra gavusi padèkas ir apdovanojimus, iš jų paminètina - 2006 metais Vilniaus jaunimo organizacijų sąjunga „Apskritasis stalas“ įteikè padèką už prasmingiausią projektą („Sniego gniūžtę") Vilniaus mieste, Narkotikų kontrolès departamentas ši projektą ịvardijo geriausiai įvertintu psichoaktyvių medžiagų vartojimo prevencijos srityje. BNO3 per nagrinėjamą laikotarpi pasižymėjo tokiose srityse: sveikos gyvensenos bei socialinių ígūdžių ugdymas ir savanorystès idejos propagavimas, savanorių mokymai; ị organizuojamus, 
skirtus vaikams ir jaunimui, renginius įtraukiami socialinės rizikos grupių atstovai; renginių vaikų dienos centruose, vaikų namuose ir t. t. organizavimas; bendruomeniškumo, demokratiškumo ir kitų nuo pilietiškumo turinio neatsiejamų vertybių propagavimas ir t. t. BNO3 aktyviai reiškiasi ir pilietinèje-politinejje dimensijoje - pozicijų dèl LR Seimo svarstomų klausimų Alkoholio politikos srityje viešinimo ir siuntimo (įteikimo) Seimo nariams; organizacijos narių dalyvavimas Seimo komitetų posėdžiuose ir pozicijų išsakymas; dalyvavimas pilietinėse akcijose, kurias organizavo socialiniai partneriai, arba savarankiškas organizavimas (pvz., visuomeninė akcija „Nusiginkluok“).

Taigi, sèkmingai vykdomos pasirinktų organizacijų veiklos žinomumas ir su ja susijusių projektų palankus vertinimas bei pilietiškai aktyvi organizacijų narių veikla leidžia teigti, kad BNO1, BNO2 ir BNO3 veikla nagrinejjamu laikotarpiu buvo naudinga visuomenei, kurianti pozityvų socialinį efektą ir gali būti priskiriama gerosios patirties atvejams.

Siekiant nustatyti pokyčius istorijos tėkmėje ir galimas tendencijas, buvo pasirinkti metai (1994-1998; 2004; 2014), kurių laikotarpiu tiriama organizacijos situacija išskirtais vadybos aspektais, tada jie apibendrinami ir formuluojamos identifikuotos tendencijos. Pažymètina, kad tik BNO2 (kuri buvo ịkurta 1992 m.) galèjo būti analizuojama viso pasirinkto laikotarpio, tuo tarpu BNO1 (ikurta $2002 \mathrm{~m}$.) nagrinèta tik paskutinijji dešimtmetị.

Empirinio tyrimo rezultatai. Nagrinėjamų organizacijų veiklos ypatumai, susiję su tiesiogine organizacijos veikla, lemè tam tikrą vadybos specifiką, tačiau tyrimas leido išskirti ir bendras tendencijas pagal vadybos aspektus, kurios pateikiamos 1 lentelèje.

BNO1 pasižymi vietos gyventojų telkimu sprendžiant bendruomenès problemas ir planuojant bendrus kultūrinius renginius. Kaip ir kitose NVO, čia svarbus yra lyderio vaidmuo bei skirtingų veiklų planavimas ir koordinavimas. Vèlesniuose bendruomenès gyvavimo etapuose, organizacijai plečiantis, ryškejjo specialiụjų kompetencijų poreikis, susijęs su stambių projektų valdymu, finansų tvarkymu ir strateginiu planavimu.

BNO2 susikūrè Lietuvai atgavus nepriklausomybę ir savo veiklą koncentravo ị paramą sveiką gyvenseną propaguojančioms organizacijoms bei viešosios politikos formavimą. Šioje organizacijoje nuo susikūrimo buvo didelis poreikis kompetencijų, susijusių su raštvedyba, projektų valdymu, komunikacija tarp organizacijų, viešosios politikos formavimo bei igyvendinimo išmanymu. Ilgainiui, stiprinant Lietuvos „trečiąji “ sektorių užsienio fondų parama, organizacija sustiprinimo kompetencijas stambiems projektams (per 100 tūkst. litų) pritraukti ir kitų NVO narių (dirbančiụ tiesiogiai su pažeidžiamomis socialinėmis grupemis) kompetencijoms kelti. Taigi, išryškẻjo stiprūs projektų rengimo ir igyvendinimo igūdžiai bei gebejimai, susiję su komandiniu darbu. Vis dèlto susitelkimas ị esamų projektų ịgvendinimą bei pastangos stiprinti bendradarbiavimą su viešosios valdžios institucijoms lèmé mažesnị dèmesį naujų organizacijos lyderių ugdymui, kas ribojo vèlesnių projektų sklandesnị igyvendinimą. BNO2 nuolatinis bendradarbiavimas su organizacijos nariais nebuvo aktualus, todèl vyravo daugiau tradiciniai (elektroninis paštas, telefonas) komunikacijos kanalai.

BNO3 susikūrẻ kaip bendraminčių grupé, kuri stipriai koncentravosi $\mathfrak{i}$ tiesioginès veiklos igyvendinimą. Projektinès veiklos iggyvendinimui šalia projektinio valdymo kompetencijų svarbus buvo žmogiškųjų išteklių valdymas, ypatingai darbas su savanoriais, jų pritraukimas ir ịtraukimas ị veiklą, glaudžių ryšių palaikymas. Dirbant su žmogiškaisiais ištekliais svarbios buvo komunikacijos ir komandinio darbo kompetencijos. Strateginio 
planavimo metodai pradèti diegti BNO3 dar iki 2004 m., tačiau strateginio valdymo procesas dažnai stringa igyvendinimo stadijoje. Viena iš pagrindinių problemų - nepakankamas naujų lyderių ugdymas ir motyvavimas igyvendinti prisiimtas atsakomybes per ilgesnị nei kalendoriniai metai laikotarpi.

Visos nagrinètos organizacijos nuo susikūrimo labiau koncentravosi i tiesioginès veiklos turinį, mažiau dėmesio skirdamos profesionaliai su šia veikla susijusių procesų vadybai. Dèl to kilo sunkumų organizacijoms plečiantis ir igyvendinant didesnius projektus. Tačiau nagrinètos organizacijos kūrybingai spręsdavo minètus sunkumus, stiprindamos narių kompetencijas specialiais vadybos srities mokymais (pažymėtina BNO3). Tikètina, kad globalizacijos sąlygomis stiprèjant bendruomeninių ir nevyriausybinių organizacijų tarpusavio bendradarbiavimui augs poreikis tobulinti kompetencijas, susijusias su komunikacija ir bendradarbiavimu.

Analizuojant BNO1, BNO2 ir BNO3 pagal nagrinejjamus laikotarpius, pastebėtina, kad organizacijos veiklų organizavimui ir komunikacijai (tiek vidinèje tarp narių, tiek su organizacijos išorine aplinka) ženklų vaidmenị vaidino skaitmeninių technologijų plètra. Išskirtos tendencijos leidžia teigti, kad skaitmeninès technologijos apims ir sudarys sąlygas efektyviau atlikti vis daugiau bendruomeninių ir nevyriausybinių organizacijų veiklų.

BNO3 pasižymèjo spartesne socialinių tinklų panaudojimo veikla. Ši tendencija aiškintina organizacijos specifiškumu - dauguma narių (per 70 proc.) jauni žmonės (14-29 m.), aktyviai besinaudojantys skaitmeninėmis technologijomis kasdieniniame gyvenime.

Apžvelgus Lietuvos bendruomeninių ir nevyriausybinių organizacijų raidą bei remiantis empiriniame tyrime analizuotų organizacijų vadybos patirtimi, pateikiami bendruomeninių ir nevyriausybinių organizacijų vadybos ypatumai ir tendencijos pagal išskirtus aspektus (žr. 1 lentelè).

1 lentele. Bendruomeninių ir nevyriausybinių organizacijų vadybos ypatumai ir tendencijos

\begin{tabular}{|c|c|c|c|}
\hline Vadybos aspektai & $1994-1998 \mathrm{~m}$. & $2004 \mathrm{~m}$. & $2014 \mathrm{~m}$. \\
\hline $\begin{array}{l}\text { Organizacijų } \\
\text { lyderiai, } \\
\text { vadovavimas } \\
\text { organizacijai }\end{array}$ & $\begin{array}{l}\text { Tarp narių dominuoja } \\
\text { pilietiškai nusiteikę, } \\
\text { ivairiose veiklose aktyvūs } \\
\text { asmenys } \\
\text { Vadybos metodai } \\
\text { taikomi intuityviai, } \\
\text { veikla ilgesniam } \\
\text { laikotarpiui planuojama } \\
\text { retai }\end{array}$ & $\begin{array}{l}\text { Vis dažniau susiduriama } \\
\text { su veiklos tęstinumo } \\
\text { problema, kurios } \\
\text { tiketinu sprendimu yra } \\
\text { identifikuojamas lyderių } \\
\text { „auginimas“ bei ugdymas } \\
\text { Priklausomai nuo } \\
\text { lyderių, gali būti taikomi } \\
\text { ir profesionalūs vady- } \\
\text { bos metodai, būdingi } \\
\text { privačiam arba viešojo } \\
\text { valdymo sektoriams } \\
\text { Dalis organizacijų rengia } \\
\text { strateginius veiklos pla- } \\
\text { nus, tačiau igyvendinimas } \\
\text { yra labiau spontaniškas } \\
\text { negu planingas }\end{array}$ & $\begin{array}{l}\text { Veiklos tęstinumo } \\
\text { problema išlieka } \\
\text { Taikomi vadybos } \\
\text { metodai yra labiau } \\
\text { adaptuoti (nei iki tol) } \\
\text { trečiajam sektoriui }\end{array}$ \\
\hline
\end{tabular}




\begin{tabular}{|c|c|c|c|}
\hline $\begin{array}{l}\text { Žmogiškųjų } \\
\text { išteklių sutelkimas } \\
\text { ir aktyvinimas } \\
\text { įtraukiant ị veiklą }\end{array}$ & $\begin{array}{l}\text { Nariai ̨̇ organizacijas } \\
\text { buriasi savaime, daugiau } \\
\text { iš ideologinių paskatų, } \\
\text { per asmeninį narių } \\
\text { kontaktą } \\
\text { Ypatingi pritraukimo } \\
\text { metodai netaikomi }\end{array}$ & $\begin{array}{l}\text { Potencialūs nariai turi } \\
\text { didesnį pasirinkimą tarp } \\
\text { skirtingų organizacijų. } \\
\text { Šioms tenka konkuruoti } \\
\text { dèl narių } \\
\text { Didelè dalis narių yra } \\
\text { migruojantys per orga- } \\
\text { nizacijas ir dalyvaujantys } \\
\text { skirtinguose renginiuose, } \\
\text { tačiau prie organizacijos } \\
\text { plètros mažai prisidedan- } \\
\text { tys } \\
\text { NVO nariai pritrauki- } \\
\text { ami per organizacijų } \\
\text { renginius; asmeninį narių } \\
\text { kontaktą; viešai prieinamą } \\
\text { informaciją organizacijų } \\
\text { tinklalapiuose }\end{array}$ & $\begin{array}{l}\text { Organizacijos taiko ino- } \\
\text { vatyvius narių pritrau- } \\
\text { kimo būdus, labiau anali- } \\
\text { zuoja narių poreikius } \\
\text { siekiant juos pritraukti } \\
\text { ir motyvuoti dalyvauti } \\
\text { veiklose } \\
\text { Didele dalis narių yra } \\
\text { migruojantys per orga- } \\
\text { nizacijas ir dalyvaujantys } \\
\text { skirtinguose renginiuose, } \\
\text { tačiau prie organizacijos } \\
\text { plètros mažai prisid- } \\
\text { edantys } \\
\text { NVO nariai pritrauki- } \\
\text { ami per organizacijų } \\
\text { renginius; asmeninị } \\
\text { narių kontaktą; viešai } \\
\text { prieinamą informaciją } \\
\text { organizacijų tinklala- } \\
\text { piuose, socialiniuose } \\
\text { tinkluose } \\
\text { Ieškoma inovatyvesnių } \\
\text { būdų pritraukti naujus } \\
\text { narius }\end{array}$ \\
\hline $\begin{array}{l}\text { Organizacijos } \\
\text { narių bendradar- } \\
\text { biavimas, } \\
\text { komandinis } \\
\text { darbas }\end{array}$ & $\begin{array}{l}\text { Bendradarbiavimas } \\
\text { ir komandinis darbas } \\
\text { atsiranda natūraliai, dèl } \\
\text { identifikavimosi su orga- } \\
\text { nizacija ir bendrų tikslų } \\
\text { jausmo } \\
\text { Komunikacija vykdoma } \\
\text { žodžiu, stacionariais } \\
\text { telefonais ir laiškais per } \\
\text { nacionalini paštą }\end{array}$ & $\begin{array}{l}\text { Taikomi komandos } \\
\text { formavimo metodai. } \\
\text { Daugiau demesio } \\
\text { skiriama bendradar- } \\
\text { biavimo ir komunikacijos } \\
\text { efektyvumui } \\
\text { Komunikacijos kanalai } \\
\text { papildomi: organizacijų } \\
\text { internetinemis } \\
\text { svetainemis; forumais } \\
\text { svetainèse; elektroniniu } \\
\text { paštu (sukuriamos } \\
\text { elektroninès } \\
\text { konferencijos); mobiliais } \\
\text { telefonais. Tradicinis } \\
\text { paštas ir stacionarūs } \\
\text { telefonai taikomi labiau } \\
\text { oficialiems kontaktams } \\
\text { palaikyti }\end{array}$ & $\begin{array}{l}\text { Taikomi komandos } \\
\text { formavimo metodai. } \\
\text { Demesys narių } \\
\text { bendradarbiavimui } \\
\text { ir komunikacijai vis } \\
\text { labiau papildomas } \\
\text { komunikacija su } \\
\text { organizacijos išore } \\
\text { Tarp komunikacijos } \\
\text { kanalų dominuoja } \\
\text { socialinių tinklų platfor- } \\
\text { mos; elektroninis paštas; } \\
\text { pradedamos taikyti } \\
\text { ìvairios skaitmeninès } \\
\text { aplikacijos, naudojamos } \\
\text { mobiliuose ịrenginiuose } \\
\text { Internetiniai tinklapiai } \\
\text { ir elektroninè (el. pašto } \\
\text { pagrindu) konferencijos } \\
\text { mažiau naudojami; foru- } \\
\text { mai dar rečiau. „Tradici- } \\
\text { nis“ paštas taikomas tik } \\
\text { išimtiniais atvejais }\end{array}$ \\
\hline
\end{tabular}




\begin{tabular}{|l|l|l|l|}
\hline $\begin{array}{l}\text { Organizacijos } \\
\text { narių } \\
\text { kompetencijos }\end{array}$ & $\begin{array}{l}\text { Vertinant pagal } \\
\text { kompetenciją dominuoja } \\
\text { švietimo sistemos } \\
\text { atstovai, kvalifikacijos } \\
\text { kélimui demesio } \\
\text { skiriama mažai }\end{array}$ & $\begin{array}{l}\text { Yra narių, turinčių ilgesnę } \\
\text { patirtị organizacijose }\end{array}$ & $\begin{array}{l}\text { Labiau gilinamasi ị orga- } \\
\text { nizacijos narių kompe- } \\
\text { tencijas bei jų trūkumus }\end{array}$ \\
& $\begin{array}{l}\text { Nariai skatinami tobulinti } \\
\text { kompetencijas, susijusias } \\
\text { su organizacijos veiklos } \\
\text { turiniu, bei dalykines } \\
\text { (pvz., projektų rengimo, } \\
\text { kompetencijuc skatinama } \\
\text { finansų apskaitos ir t. t.) } \\
\text { kompetencijas }\end{array}$ & $\begin{array}{l}\text { kggdyti ir bendrąsias } \\
\text { (pvz., lyderiavimo) }\end{array}$ \\
& & & \\
\hline
\end{tabular}

Šaltinis: parengta autoriaus.

\section{Išvados}

1. Išnagrinėjus bendruomeninių ir nevyriausybinių ne pelno organizacijų veiklos tikslus, galima išskirti pagrindinius vadybos aspektus, turinčius įtakos organizacijos sèkmingai (veiksmingai) veiklai: 1) organizacijų lyderiai, vadovavimas organizacijai; 2) žmogiškuju išteklių sutelkimas ir aktyvinimas (motyvavimas) įtraukiant ị veiklą; 3) organizacijos nariu bendradarbiavimas, komandinis darbas; 4) organizacijos narių kompetencijos.

2. Apžvelgus bendruomeninių ir nevyriausybinių ne pelno organizacijų raidą Lietuvoje galima teigti, kad organizacijų skaičiaus augimui turejjo ịtakos tiek valstybès vidaus (sudarytos teisinès sąlygos burtis ị organizacijas, piliečių noras spręsti tiek vietos bendruomenès, tiek plačios visuomenès problemas), tiek išorès (paminètina užsienio valstybių parama trečiajam sektoriui) veiksniai. Lietuvoje pilietinė visuomené dar tik formuojasi, todèl valstybinio valdymo institucijų vaidmuo, siekiant sudaryti palankesnes sąlygas „trečiojo“ sektoriaus plètrai yra vienas iš lemiančių veiksnių.

3. Ištyrus pasirinktų bendruomeninių ir nevyriausybinių ne pelno organizacijų veiklos tęstinumą, galima identifikuoti tokias organizacijų vadybos tendencijas:

1) organizacijos veiklos tęstinumo problemos dèl naujų lyderių rengimo stokos išlieka aktualios, tačiau pradedami taikyti nauji inovatyvūs metodai; organizacijos vis dažniau taiko strateginio planavimo metodus;

2) narių pritraukimui ir motyvavimui taikoma daugiau inovatyvių vadybos metodų, susijusių su socialiniais tinklais ir elektroninèmis mobiliosiomis technologijomis;

3) tarp komunikacijos kanalų dominuoja socialinių tinklų platformos; elektroninis paštas; pradedamos taikyti įvairios skaitmeninès aplikacijos, naudojamos mobiliuose ịrenginiuose.

4) išsamiau analizuojamos organizacijos narių kompetencijos ir jų poreikiai.

4. Atsižvelgiant $\mathfrak{i}$ ištirtas bendruomeninių ir nevyriausybinių organizacijų vadybos tendencijas galima daryti prielaidas dèl vadybos perspektyvų: 1) globalizacijos sąlygomis stiprejjant bendruomeninių ir nevyriausybinių organizacijų tarpusavio bendradarbiavimui augs poreikis tobulinti kompetencijas, susijusias su komunikacija ir bendradarbiavimu; 2) žmogiškųjų išteklių vadyboje turès daugèti inovatyvių vadybos metodų, atitinkančių besikeičiančios organizacijos aplinkos ir narių kompetencijų kaitos 
tendencijas; 3) stiprès skaitmeninio turinio technologinių įrankių poreikis organizacijų vadyboje.

\section{Rekomendacijos}

Empirinio tyrimo rezultatai atskleidè „trečiojo“ sektoriaus organizacijų vadybos trūkumus žmogiškųjų išteklių valdymo srityje (ypatingai naujų narių pritraukimo ir motyvavimo bei lyderių ugdymo). Esama situacija susiformuoja dèl šio sektoriaus specifiškumo, lyginant su privačiuoju bei valstybinio valdymo. Todèl siekiant stiprinti bendruomeninių ir nevyriausybinių organizacijų žmogiškųjų išteklių potencialą, rekomenduotina plètoti tyrimus vadybos srityje, leidžiančius labiau išskirti „trečiojo“ sektoriaus specifiškumą ir jam adaptuotus vadybos ịrankius bei gerųjų patirčiu perteikimo galimybes.

Tyrimo metu išskirtos vadybos tendencijos sudaro prielaidas rekomenduoti viešajai valdžiai, siekiančiai plètoti „trečiąjį sektorių ir puoselèti pilietiškumą, kryptingiau veikti ir skirti daugiau dèmesio stiprinant bendruomeninių ir nevyriausybinių organizacijų kompetencijas, susijusias su (i) komunikacija, naudojant skaitmenines technologijas, bei (ii) strateginiu ir (iii) žmogiškųjų išteklių valdymu.

\section{Literatūra}

Aleksandravičius, A.; Žukovskis, J. 2011. Kaimo bendruomenių raida ir jų veiklos tikslai: siekiant darnumo visuomeneje. Vadybos mokslas ir studijos - kaimo verslu ir ju infrastruktūros plètrai. 1 (25): 7-15.

Ališauskas, K.; Jankauskienè, A.; Kairyte, L. 2008. Nuostatų kaita kaimo bendruomenių veikloje. Ekonomika ir vadyba: aktualijos ir perspektyvos. 3 (12): 5-13.

Bagdonienè, D.; Daunorienè, A.; Simanavičienè, A. 2011. Nevyriausybinių organizacijų veiklos kokybès ir efektyvumo vertinimas. Ekonomi$k a$ ir vadyba. 16: 654-663 [žiūrèta 2014-0412]. <http://www.ktu.lt/lt/mokslas/zurnalai/ ekovad/16/1822-6515-2011-0654.pdf>.

Banks, N.; Hulme, D. 2012. The Role of NGOs and Civil Society in Development and Poverty Reduction. BWPI Working Paper [žiūrèta 2013-04-12]. <http://www.bwpi.manchester.ac.uk/resources/Working-Papers/bwpiwp-17112.pdf>.

Blackshaw, T. 2010. Key Concepts in Community Studies. London: Sage Publications, 232 p.
Block, P. 2008. Community: The Structure of Belonging, San Francisco: Berrett-Koehler Publishers, 2008, 257 p.

Čepienè, A. 2011. Kaimo bendruomenès narių socialinio dalyvavimo teorinès ižzalgos. Profesines studijos: teorija ir praktika. 8: 124-130.

Domański, J. 2010. Zarządzanie strategiczne i jego modele dla organizacjami non profit [žiūrèta 2013-09-12]. <http://www.ptzp.org. pl/files/konferencje/kzz/artyk_pdf_2010/39_ Domanski_J.pdf>.

Drucker, P. 1995. Zarządzanie organizacją pozarządową. Teoria i praktyka, Fundusz współpracy: Warszawa.

Etzioni, A. 2011. Nationalism: The Communitarian Block. The Brown Journal of Worlds Affairs. 18 (1): 229-247.

Fung, A. 2003. Associations and democracy: Between theories, hopes, and realities. Annual Review of Sociology. 29: 515-539 [žiūrèta 2011-06-12]. <http://www.abdn.ac.uk/sociology/notes06/Level4/SO4530/Assigned-Readings/Lecture\%209.1.pdf $>$. 
Grigas, R. 2010. Bendruomeniškumo ir savivaldos Lietuvoje kaitos bruožai: istoriosofine interpretacija. Konferencija „Vietos savivalda ir bendruomenes Lietuvoje". Vilnius, 201002-10 [žiūrèta 2013-04-12]. <http://vinilas.lt/ lvbos/siuntiniai/Konferencija1.pdf>.

Guogis, A.; Gudelis, D.; Stasiukynas, A. 2007. Nevyriausybinių organizacijų ir savivaldybių santykių reikšmė plètojant vietinę demokratiją: atvejo tyrimai dviejose Lietuvos savivaldybèse. Viešoji politika ir administravimas. 22.

Ilgius, V. 1999. Filantropija - nuo išimčiu prie tradicijos. Lietuvos laisvosios rinkos instituto konferencija, Vilnius [žiūrèta 2011-06-12]. $<$ http://old.nisc.lt/nvo_lietuvoje.php $>$.

Jakutytė, K. 2012. Nevyriausybinių organizacijų veiklų igyvendinimas e. dalyvavimo aspektu. Viešoji politika ir administravimas. 11(2).

Juozaitis, A. M.; Vilimiené, R. 2000. Nevyriausybinès organizacijos: nuo aiškios strategijos link efektyvios veiklos. Vilnius: Danielius.

Kèryte, Ž. 2010. Pilietiškumo konstravimas globalumo kontekste: NVO vaidmens kaita Lietuvoje. Kultūra ir visuomene. 1(2).

Lecy, J.; Schmitz, H. P.; Swedlund, H. 2012. NGO and NPO Effectiveness: A Modern Synthesis. Voluntas. 23 (2): 434-457.

Lewis, D. 2000. Management of Non-Governmental organizations: Catalysts, Partners and Implementors. Routledge, p. 68-69.

Lietuvos Respublikos vietos savivaldos istatymas. Valstybès žinios. 1994, Nr. 55-1049.

Lietuvos Respublikos vietos savivaldos ístatymo pakeitimo įstatymas. Valstybès žinios. 2008, Nr. 113-4290.

Mačiukaitė-Žvinienė, S.; Grigaliūnaitè, J. 2006. Looking for Civil Participation in the Baltic
States: Non-Governmental Sector. Viešoji politika ir administravimas. 17: 115-123.

Marček, E. 2008. Dialog między władzą i organizacjami pozarządowymi na Słowacji - lata 1992-2008. Organizacje pozarzadowe $i$ wtadza publiczna. Drogi do partnerstwa, red. G. Makowski, T. Shimanka, Warszawa.

Matonyte, I. 2003. Pilietinès visuomenès tyrimo teorinès perspektyvos. Viešoji politika ir administravimas. 5.

McMillan, D. W.; Chavis, D. M. 1986. Sense of Community: A Definition and Theory. Journal of Community Psychology. 14(1): 3-9.

Nefas, S. 2007. Funkcionali vietos bendruomenè Lietuvos kaimuose ir miesteliuose. Daktaro disertacija. Vilnius: Mykolo Romerio universitetas.

Nefas, S. 2007. Savivaldžių (vietos) bendruomenių raida ir perspektyva šiuolaikineje Lietuvoje. Viešoji politika ir administravimas. 20.

Nefas, S. ir kt. 2011. Demokratija ir vietos bendruomene Lietuvoje. Vilnius: Mykolo Romerio universitetas.

Schmitz, P. 2011. Everyone Leads: Building Leadership from Community Up. San Francisco: Jossey - Bass.

Stasiukynas, A.; Žuromskaite, B. 2014. Jaunimo nevyriausybinès organizacijos LKJBS „Žingsnis“ vertybès - sèkmingos veiklos pagrindas. Mokslo studija: Veiksmingos vadybos gairès: teorines j̨žvalgos ir Lietuvos organizacijų atvejai. P. 96-119.

Šimašius, R. 2007. Ne pelno organizacijos. Prigimtis ir reglamentavimas. Vilnius.

\title{
TRADITIONS AND MANAGEMENT PERSPECTIVES OF COMMUNITY AND NON-PROFIT ORGANIZATIONS IN LITHUANIA
}

\author{
Andrius Stasiukynas \\ Mykolas Romeris University, Lithuania, stasiukynas@mruni.eu
}

\section{Summary}

Purpose - To overview the traditions and management perspectives of community and non-profit organizations in Lithuania. 
Methodology - For the purpose of this research a literature analysis on community and non-profit organization case studies was conducted. The case studies describing stories of success were singled out and leaders of these organizations were interviewed.

Findings - The research has showed the grow th of the number of community and nonprofit organizations during the last twenty years and the difficulties of collecting the statistical data. This study presupposes the possibility to identify the tendencies of management in community and non-profit organizations, including the following: increasing use of the social networks for communication; proliferation of strategic planning; greater emphasis on educating and empowering new generation of leaders.

Research implications - Prior studies in this area in Lithuania have not exhaustively analyzed the components of human resource management of non-profit organizations. An important follow up on this study would be to analyze the human resource management in community organizations.

Practical implications - This study covered the management aspects important for the improvement of how community and non-profit organizations work.

Originality/Value - This study expands the knowledge on Lithuanian community and non-profit organization development and management.

Keywords - community, non-profit organization, management of community and non-profit organizations.

Research type - literature review, research paper. 